\title{
REVIEW
}

\section{Meta-analysis of the association of enteroviruses with human heart disease}

\author{
Christina Baboonian, Tom Treasure
}

\begin{abstract}
The role of viruses in the genesis of both dilated cardiomyopathy (DCM) and acute myocarditis remains uncertain. Modern molecular techniques such as polymerase chain reaction (PCR) and in situ hybridisation are sensitive means of detecting viral genomic material in human myocardial tissue and may help to resolve the quest. Meta-analysis of the papers in the literature records studies of both acute myocarditis and DCM where molecular techniques were used to demonstrate enteroviruses. This review studies information from the published literature as well as statistical analysis of the cumulative molecular data relating enteroviruses to DCM, and to compare these findings with the information available on the role of enteroviruses in acute myocarditis. Twelve papers reported studies in acute myocarditis, of which 11 found higher percentages of enteroviral RNA positivity in the diseased population, giving an overall odds ratio of 4.4. Seventeen papers reported studies in DCM, with 11 recording higher positivity rates in these patients. Cumulative analysis of these data suggests an overall odds ratio of 3.8. The causative role of enteroviruses in acute myocarditis, particularly in children, is supported by meta-analysis of the available literature. The data on DCM is suggestive of an association but a proportion of the studies are negative. (Heart 1997;78:539-543)
\end{abstract}

Keywords: enteroviruses; dilated cardiomyopathy; myocarditis; meta-analyses

Department of

Cardiological

Sciences, St George's

Hospital Medical

School, Cranmer

Terrace, Tooting,

London SW17 0RE, UK

$\mathrm{T}$ Treasure

C Baboonian

Correspondence to:

Dr Baboonian.

Accepted for publication 4 September 1997

Reports of an association between enteroviruses and myocarditis date back to 1956 when coxsackie B4 virus was isolated from the heart tissue of a neonate with fatal infection. ${ }^{1}$ Four decades later debate continues on the role of enteroviruses in acute and chronic myocardial disease.

Coxsackie $\mathrm{B}$ viruses are ubiquitous enteroviruses that spread rapidly within the community causing small epidemics with a high proportion of subclinical cases. Symptomatic infection ranges in severity from mild undifferentiated febrile illness or upper respiratory tract infection to severe systemic disease of neonates. Historically, it was the childhood cases of myocarditis that attracted attention to this group of agents. ${ }^{1-4}$ Early reports of epidemics in maternity homes where virus was isolated from peripheral sites of neonates, ${ }^{23}$ were followed by studies confirming the presence of coxsackieviruses in the heart tissue of infants with myocarditis. ${ }^{15}$ Later work showed that infection during pregnancy may result in fetal damage d-8 $^{6-8}$ and large scale serological studies confirmed that mothers of infants with cardiological abnormalities were more likely to be infected with coxsackievirus B than were controls. ${ }^{4}$

Studies of a causal link between enteroviruses and adult cases of myocarditis proved more difficult. Virus isolation from adult heart tissue is very uncommon, ${ }^{9-11}$ and until recently many epidemiological studies relied on either virus culture from peripheral sites or serological investigations for diagnosis. As enteroviruses circulate freely in the community and virus can be cultured from the pharynx and faeces for several weeks following infection, diagnostic value cannot be attached to virus isolation from these sites. Serological studies are also fraught with difficulties as high titre antibodies can persist for prolonged periods in some individuals. Moreover, unlike young children, adults with prior exposure to enteroviruses may show a heterotypic rise in antibody titres confusing the diagnosis. Despite these problems, comparison of recent serological studies ${ }^{12-14}$ shows that $33-36 \%$ of adults with acute myocarditis have either rising titres of neutralising antibodies to coxsackie B viruses or have enterovirus specific IgM class antibodies indicative of a recent infection. The rate of infection in the control groups in these reports varies between $4 \%$ and $10 \%$.
The advent of molecular techniques for the detection of viral RNA facilitated studies of heart tissue in non-fatal cases, providing an indication of the prevalence of these agents in acute myocarditis. Using in situ hybridisation, Hilton et al found $20 \%$ of childhood cases of acute myocarditis to carry enteroviral RNA in heart tissue. ${ }^{15}$ This result was confirmed by Martin et al who, using polymerase chain 


$\begin{array}{ll} & \\ \text { Jin } & 1990 \\ \text { Towbin } & 1996 \\ \text { Weiss } & 1991 \\ \text { Hilton } & 1993 \\ \text { Martin } & 1994 \\ \text { Petitjean } & 1992 \\ \text { Giacca } & 1994 \\ \text { Koide } & 1992 \\ \text { Satoh } & 1994 \\ \text { Bowles } & 1986 \\ \text { Ueno } & 1995 \\ \text { Nicholson } & 1995 \\ \text { Summary } & \end{array}$

$\begin{array}{rr}\mathrm{X} & \mathrm{N} \\ 2 & 28 \\ 23 & 135 \\ 1 & 5 \\ 2 & 10 \\ 8 & 34 \\ 3 & 10 \\ 1 & 3 \\ 3 & 9 \\ 12 & 36 \\ 4 & 8 \\ 4 & 5 \\ 5 & 6 \\ 68 & 289\end{array}$
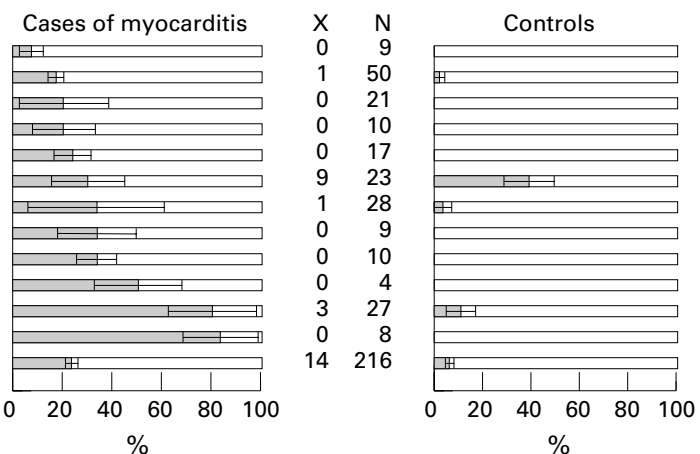

Figure 1 Evidence for association of enteroviruses with idiopathic myocarditis. The bar charts show the percentage of samples found to be positive with error bars showing the standard error of the binomial distribution. ( $X$ is the number of samples with enteroviral sequences and $N$ the total number studied.)

reaction (PCR), found eight of 38 heart biopsies taken from children with acute myocarditis and none of 17 controls carried enteroviral sequences. ${ }^{16}$ Recent work by Towbin $e t$ al has extended these findings and shown that 23 of 135 paediatric patients were enterovirus positive by PCR. ${ }^{17}$

The benefits of using molecular techniques were of particular importance in studies of adult cases of myocarditis. Some of the difficulties associated with the traditional methods of diagnosis were overcome with the widespread use of PCR. Although diverse rates of viral RNA detection in heart tissue have been reported, ${ }^{18}{ }^{19}$ there is now general agreement that there is an association between coxsackievirus $\mathrm{B}$ infection and myocarditis. The techniques applied to the study of viral aetiology in acute disease have also been used in the study of dilated cardiomyopathy (DCM). It is the aim of this report to study information from the published literature and carry out statistical analysis of the cumulative molecular data relating enteroviruses to DCM and compare these findings with the information available on the role of enteroviruses in acute myocarditis.

\section{Methods}

Analysis of the literature that records the use of molecular biological techniques such as PCR and in situ hybridisation for the detection of viral genomic material in acute myocarditis and
DCM was carried out. Totally negative studies were included but those without a control group were excluded. The results were expressed as bar charts showing the percentage of samples found to be positive and the standard error of the binomial distribution.

\section{Results}

In acute myocarditis, analysis of the molecular data for both adult and childhood cases shows that 11 of 12 studies reviewed record a higher number of patients with myocarditis positive for viral genomic material compared with controls (fig 1). ${ }^{15-26}$ The cumulative data from these studies shows that $23 \%$ of patients with disease (68 of 289 cases) and $6 \%$ of controls (14 of 216 individuals studied) were positive for enteroviral sequences, giving an odds ratio of 4.4 (95\% confidence interval (CI), 2.4 to 8.2 ).

Figure 2 summarises most recent studies of DCM where patients and control groups have been compared using molecular techniques. ${ }^{18}{ }^{20-22} 25-37$ Overall, 406 patients with DCM and 438 control subjects have been investigated with approximately $23 \%$ of the patients and $7 \%$ of controls showing evidence of enteroviral infection. The odds ratio was calculated to be 3.8 (95\% CI, 2.1 to 4.6$)$. The percentage positivity in patients with DCM varied between $0 \%{ }^{20} 28$ and $75 \% .^{37}$

\begin{tabular}{|c|c|c|c|c|}
\hline & & $\mathrm{x}$ & $\mathrm{N}$ & Cases of cardiomyopathy \\
\hline Weiss & 1991 & 0 & 11 & $\square^{-}$ \\
\hline Grasso & 1992 & 0 & 21 & $\square$ \\
\hline Liljeqvist & 1993 & 0 & 35 & $\square$ \\
\hline Muir & 1996 & 1 & 25 & 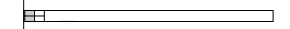 \\
\hline Giacca & 1994 & 4 & 53 & H \\
\hline Keeling & 1992 & 6 & 50 & मE \\
\hline Jin & 1990 & 3 & 20 & $\risingdotseq$ \\
\hline Ueno & 1994 & 7 & 42 & मन \\
\hline Zoll & 1992 & 1 & 5 & एव \\
\hline Marti & 1996 & 4 & 16 & 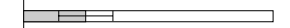 \\
\hline Bowles & 1989 & 6 & 21 & मान \\
\hline Schwaiger & 1993 & 6 & 19 & एम \\
\hline Khan & 1994 & 8 & 15 & $\longmapsto$ \\
\hline Bowles & 1986 & 5 & 9 & 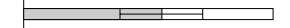 \\
\hline Andreoletti & 1995 & 10 & 15 & $\longmapsto$ \\
\hline Petitjean & 1992 & 30 & 45 & मा \\
\hline Chiang & 1992 & 3 & 4 & 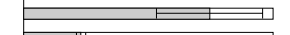 \\
\hline Summary & & 94 & 406 & \begin{tabular}{|l|l|l|} 
& $H$ \\
\end{tabular} \\
\hline & & & & $\begin{array}{llllll}0 & 20 & 40 & 60 & 80 & 100\end{array}$ \\
\hline
\end{tabular}

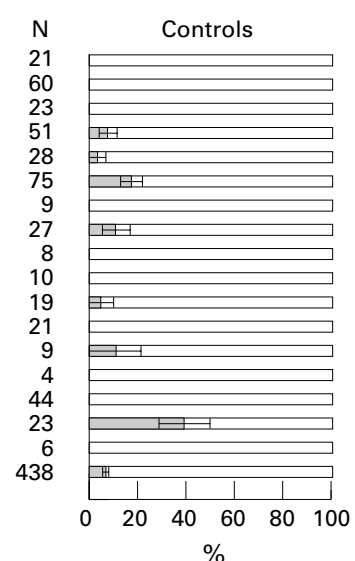

Figure 2 Evidence for association of enteroviruses with dilated cardiomyopathy. The bar charts show the percentage of samples found to be positive with error bars showing the standard error of the binomial distribution. ( $X$ is the number of samples with enteroviral sequences and $N$ the total number studied.) 


\section{Discussion}

Although an odds ratio of 3.8 is suggestive of an association between virus infection and DCM, on closer analysis, six of 17 reports found no significant differences between cases and controls (fig 2). Other studies included in this report used small numbers of patients making statistical analysis of the data difficult. Three of these investigations that found $20 \%$, $28 \%$, and $75 \%$ viral RNA carriage rates in the DCM group and no enteroviral sequences in the controls, included fewer than 10 patients. ${ }^{25} 3137$ Five of the eight remaining reports that used PCR to detect viral material did not sequence the amplification products. As the amplification procedure is particularly prone to contamination, often from the reference strain used in the laboratory, sequencing of the products is informative, confirming the origin of the virus. In one study where sequencing was undertaken the amplification products were found to be identical to the coxsackevirus B3 positive control used in the routine assay. ${ }^{22}$ In another carefully controlled study where fivefold differences in enteroviral RNA positivity were recorded with sequencing data confirming the results, patients with inflammatory heart disease were grouped together with cases of DCM..$^{35}$ Although this study has been included in the overall analysis of the role of enteroviruses in DCM, it is by no means certain that the positive patients were not cases of acute myocarditis.

A factor that further influences the interpretation of these studies is the choice of controls. As enteroviruses cause small epidemics there is likely to be variation in the virus carriage rates in different populations. In studies where serological analysis have been carried out often a significant difference in the $\operatorname{IgM}$ positivity rates between patients with DCM and controls have been observed. ${ }^{29} 3839$ However, Keeling et al found that if the serological status of patients was compared with their own family members or close associates then $37 \%$ of the disease population and $28 \%$ of the controls were $\operatorname{IgM}$ positive. $^{38}$ Taking into account the numbers involved in each group a relative risk of 1.5 can be deducted. In the same study risk seemed much higher if patients were compared with an unselected control population $(33 \%$ of the patients with DCM and $5 \%$ of the controls). When conducting serological investigations it is possible to obtain samples from close relatives or work associates exposed to the same environment and therefore likely to have experienced similar infections. Such comparisons are impossible when heart biopsy samples are analysed for viral RNA. Epidemiological data on unmatched groups, for a virus known to cause small local epidemics, may therefore be biased.

The studies cited here and numerous case reports based on traditional virus isolation, serology, and molecular techniques have strengthened the belief that there is a link between myocarditis and enterovirus infections. The relation between these viruses and chronic heart disease however remains uncertain. There are reports of coxsackievirus infections in mice resulting in histological changes resembling congestive cardiomyopathy ${ }^{40}$ and in hamsters resulting in cardiomegaly. ${ }^{41}$ Experimental work in animals has otherwise been mainly concerned with the study of myocarditis and the mechanisms of induction of disease during the acute phase of illness. Although there are animal models of DCM, these are on the whole hereditary ${ }^{42}$ or chemically induced cases. ${ }^{43-46}$ There is a paucity of experimental data on the possible progression of disease from viral myocarditis to DCM.

If enteroviruses are involved in DCM, the question arises as to the mechanism of such damage. Large scale cell death as a consequence of lytic viral infection is unlikely to cause the symptoms, as the proportion of cells infected with virus would be higher than that observed using the in situ hybridisation method. ${ }^{29}$ Indeed a number of studies have resorted to the very sensitive technique of nested $\mathrm{PCR}^{22}{ }^{35}$ for viral detection, suggesting that by the stage clinical symptoms of DCM become apparent, the quantity of persistent RNA in the heart tissue is either small or localised. While the pathological changes seen in acute myocarditis are compatible with injury caused as a consequence of infection with a lytic virus and the immune response following such infection, the structural alterations required at cellular level to cause DCM are more difficult to interpret in the context of a viral disease. Immune mediated damage to the heart as a mechanism of pathogenesis for DCM is at present speculative. Studies in mice have shown that coxsackieviruses are able to lyse myocytes $^{47}$ with maximal myocyte damage occurring either concurrently with the highest virus titres, in the case of coxsackievirus B1 and B4, ${ }^{48}$ or with the initiation of an immune response following coxsackievirus B3 infection. ${ }^{49}$ It is feasible therefore that virus may cause damage either by rapid necrosis of the heart tissue or by a more subtle immunological mechanism. As virus slowly replicates and moves from cell to cell, infected areas of the tissue may be progressively destroyed by the action of cytotoxic $\mathrm{T}$ lymphocytes. The interaction between persistent infection and immune response to the agent may cause sufficient cellular damage to initiate disease. Experimental studies in mice have shown that different components of the immune system play a role in the survival of the infected animals. Mice lacking CD4 positive cells are more likely to develop myocarditis but those without functional $\mathrm{T}$ cytotoxic cells survive longer ${ }^{50}$ and are less likely to develop myocarditis. Which component of the immune response is most active during a low grade infection in man and against which viral proteins is at present unknown.

An alternative hypotheses for which there is some epidemiological and experimental evidence is the possibility that infection with enteroviruses may trigger an exaggerated immune response not only to the viral antigens but to the host tissue. Experimental work on mice with severe combined immunodeficiency has shown that transfer of peripheral blood leucocytes of patients with chronic myocarditis to these animals causes an impairment of left ventricular function ${ }^{51}$ suggesting a cell medi- 
ated autoimmune response in the patient. Damage by autoantibodies has also been considered with a number of studies reporting higher frequencies of antibodies directed against cardiac myosin in patients with DCM. ${ }^{52}{ }^{53}$ Whether these antibodies cause cellular damage is unknown.

The precise role of each viral strain in acute or chronic infection is also uncertain. Virus isolations from fatal cases of myocarditis provide information on the serotype of the agent involved but do not give an indication of the incidence of myocarditis following infection with these commonly occurring viruses. On the other hand, most studies that have compared diseased heart tissue with controls using molecular techniques have employed group specific primers and probes, and have not attempted to distinguish between different members of the enterovirus family. ${ }^{1826303637}$ Experimental work on mice has shown that some strains of coxsackievirus B3 are more cardiovirulent than others ${ }^{54}$ and that pathogenicity may differ significantly not only between clinical isolates but also in different species or strains of animals. ${ }^{55}$

This research was supported by a grant from the British Heart Foundation. The authors thank Jocelyn Lovegrove for statistical advice.

1 Van Creveld S, DeJager H. Myocarditis in new-borns caused by Coxsackie virus. Clinical and pathological data. Ann by Coxsackie virus. Clin

2 Javett SN, Heyman S, Mundel B, Pepler WJ, Lurie HI, Gear $\mathrm{J}$, et al. Myocarditis in the new-born infant. F Pediatr 1956; 48:1- 22 .

3 Montgomery J, Gear J, Prinsloo FR, Kahn M, Kirsh ZG. Myocarditis of new-born; outbreak in maternity home in Southern Rhodesia associated with coxsackie group B virus infection. S Afr Med F 1955;29:608-18.

4 Brown GC, Karunas RS. Relationship of congenital anomalies and maternal infection with selected enteroviruses. $A n$ f Epidemiol 1972;95:207-17.

5 Zvizdic S, Seric K, Radovic S, Selak I. Izolacija virusa iz obdukcionog materijala za vrijeme epidemije coxsackie viroza, u Sarajevu 1985. Med Arh 1990;44:39-42.

6 Burch GE, Sun SC, Chu K, Sohal R, Colcolough H. Interstitial and coxsackie virus B myocarditis in infants and children. A comparative histologic and immunofluorescent study of 50 autopsied hearts. $¥ A M A$ 1968;203:1-8.

7 Basso NG, Fonseca ME, Garcia AG, Zuardi JA, Silva MR Outani $\mathrm{H}$. Enterovirus isolation from foetal and placental Outani H. Enterovirus isolation f
tissues. Acta Virol 1990;34:49-57.

8 Dommergues M, Petitjean J, Aubry MC, Delezoide AL, Narcy F, Fallet- Bianco C, et al. Fatal enteroviral infection with cerebral ventriculomegaly and cardiomyopathy. Fetal Diag Ther 1994;9:77-78.

9 Longson M, Cole FM, Davies D. Isolation of a coxsackie virus group B, type 5, from the heart of a fatal case of myocarditis in an adult. $\mathcal{F}$ Clin Pathol 1969;22:654-8.

10 Monaldi TD, Benedetto A, Montalto TT. Pericarditis infection due to coxsackie virus group $\mathrm{B}$, type 2 . $B M \mathcal{F}$ 1963;ii:1451-2.

11 Soutar CA. Unusual case of viral pericarditis. Lancet 1971;i: 498.

12 El-Hagrassy MMO, Banatvala JE, Coltart DJ. Coxsackie-Bvirus-specific IgM responses in patients with cardiac and virus-specific IgM responses in patie
other diseases. Lancet 1980;ii: $1160-2$.

13 Bell EJ, McCartney RA. A study of coxsackie B virus infections, 1972-1983. F Hyg 1984;93:197-203.

14 McCartney RA, Banatvala JE, Bell EJ. Routine use of u-antibody capture ELISA for serological diagnosis of coxsackie B virus infections. $\mathcal{F}$ Med Virol 1986;19:205-12.

15 Hilton DA, Variend S, Pringle JH Demonstration of coxsackie virus RNA in formalin-fixed tissue sections from childhood myocarditis cases by in situ hybridization and polymerase chain reaction. I Pathol 1993;170:45-51.

16 Martin AB, Webber S, Fricker J, Jaffe R, Demmler G, Kearney $\mathrm{D}$, et al. Acute myocarditis. Rapid diagnosis by PCR in children. Circulation 1994;90:330-9.

17 Towbin JA. Diagnosis and management of myocarditis in children. The second international meeting on advances in understanding and management of the cardiomyopathies [abstract]. La Coruna, Spain, 1996.

18 Jin O, Sole MJ, Butany JW, Chia WK, McLaughlin PR, Liu $\mathrm{P}$, et al. Detection of Enterovirus RNA in myocardial biopsies from patients with myocarditis and cardiomyopathy using gene amplification by polymerase chain reaction. Circulation 1990;82:8-16.
19 Nicholson F, Ajetunmobi JF, Shackleton EA, Starkey WG, Illavia SJ, Muir P, et al. Molecular detection and serotype analysis of enterovirus RNA in archival specimens from patients with acute myocarditis. Br Heart f 1995;74:522-7.

20 Weiss L, Movahed L, Billingham ME, Cleary ML. Detection of coxsackie B3 RNA in myocardial tissues by polymerase chain reaction. Am f Pathol 1991;138:497-503.

1 Petitjean J, Kopecka H, Freymuth F, Langlard JM, Scanu P, Galateau F, et al. Detection of enteroviruses in endomyocardial biopsy by molecular approach. f Med Virol 1992;37:76-82.

22 Giacca M, Severini GM, Mestroni L, Salvi A, Lardieri G, Falaschi A, et al. Low frequency of detection by nested polymerase chain reaction of enterovirus ribonucleic acid in endomyocardial tissue of patients with idiopathic dilated cardiomyopathy. $\mathcal{F}$ Am Coll Cardiol 1994;24:1033-40.

23 Koide H, Kitaura Y, Deguchi H, Ukimura A, Kawamura K, Hirai K. Genomic detection of enteroviruses in the myocarditis and endomyocardial biopsies from patients with myocarditis and dilated cardiomyopathy. Fpn Circ $\mathcal{F}$ 1992;56:1081-93.

24 Satoh M, Tamura G, Segawa I. Enteroviral RNA in endomyocardial biopsy tissues of myocarditis and dilated cardiomyopathy. Pathol Int 1994;44:345-51.

25 Bowles NE, Richardson PJ, Olsen EGJ, Archard LC. Detection of coxsackie B virus specific RNA sequences in myocardial biopsy samples from patients with myocarditis and dilated cardiomyopathy. Lancet 1986;i:1120-3.

26 Ueno H, Yokota Y, Shiotani H, Yokoyama M, Itoh H, Ishido $\mathrm{S}$, et al. Significance of detection of enterovirus RNA in myocardial tissues by reverse transcription-polymerase myocardial tissues by reverse transcription

27 Grasso M, Arbustini E, Silini E, Diegoli M, Percivalle E, Ratti G, et al. Search for coxsackie virus B3 RNA in idiopathic dilated cardiomyopathy using gene amplification by polymerase chain reaction. Am 7 Cardiol 1992;69:65864 .

28 Liljeqvist JA, Bergstrom T, Holmstrom S, Samuelson A, Yousef GE, Waagstein F, et al. Failure to demonstrate nterovirus aetiology in Swedish patients with dilated cardiomyopathy. 7 Med Virol 1993;39:6-10.

29 Muir P, Nicholson F, Illavia SJ, McNeil TS, Ajetunmobi JF, DunnH, et al. Serological and molecular evidence of enterovirus infection in patients with end-stage dilated cardiomyopathy. Heart 1996;76:243-9.

30 Keeling PJ, Jeffrey S, Caforio ALP, Taylor R, Bottazzo GF, Davies MJ, et al. Similar prevalence of enteroviral genome within the myocardium from patients with idiopathic dilated cardiomyopathy and controls by the polymerase chain reaction. Br Heart $\mathcal{f} 1992 ; 68: 554-9$.

31 Zoll GJ, Melchers WJG, Kopecka H, Jambroes G, van der Poel HJA, Galama MD. General primer-mediated polymerase chain reaction for detection of enteroviruses: polymerase chain reaction for detection of enteroviruses: Application for diagnostic routine

32 Marti V, Coll P, Ballester M, Obrador D, Carrio I, Moya C, et al. Enterovirus persistence and myocardial damage detected by $111 \mathrm{In}$-monoclonal antimyosin antibodies in patients with dilated cardiomyopathy. Eur Heart f 1996;17: 545-9.

33 Bowles NE, Rose ML, Taylor P, Banner NR, MorganCapner P, Cunningham L, et al. End-stage dilated cardiomyopathy persistence of enterovirus RNA in myocardium at cardiac transplantation and lack of immune response. Circulation 1989;80:1128-36.

34 Schwaiger A, Umlauft F, Weyrer K, Larcher C, Lyons J, Muhlberger V, et al. Detection of enteroviral ribonucleic acid in myocardial biopsies from patients with idiopathic dilated cardiomyopathy by polymerase chain reaction. $\mathrm{Am}$ Heart f 1993;126:406-10.

35 Khan M, Why H, Richardson P, Archard L. Nucleotide sequencing of PCR products shows the presence of coxsackie-B3 virus in endomyocardial biopsies from patients with myocarditis or dilated cardiomyopathy. Biochem Soc Trans 1994;22:176S

36 Andreoletti L, Wattre P, Decoene C, Lobert PE, Dewilde A, Hober D. Detection of enterovirus-specific RNA sequences in explanted myocardium biopsy specimens from patients with dilated or ischaemic cardiomyopathy. Clin Infect Dis 1995;21:1315-17.

37 Chiang FT, Lin Li, Tseng YZ, Tseng CD, Hsu KL, Wu TL, et al. Detection of enterovirus RNA in patients with idiopathic dilated cardiomyopathy by polymerase chain reaction. Taiwan I Hsueh Hui Tsu Chih 1992;91:569-74.

38 Keeling PJ, Lukaszyk A, Poloniecki J, Caforio ALP, Davies MJ, Booth JC, et al. A prospective case-control study of antibodies to coxsackie $\mathrm{B}$ virus in idiopathic dilated cardiomyopathy. I Am Coll Cardiol 1994;23:593-8.

39 Cambridge G, MacArthur CG, Waterson AP, Goodwin JF, Oakley CM. Antibodies to coxsackie B viruses in congestive cardiomyopathy. Br Heart f 1979;41:692-6.

40 Kutaura Y. Experimental coxsackie B virus myocarditis in mice: 18 month histopathological and virological study. $f p n$ Circ f 1981;45:747-62.

41 Morita H. Experimental coxsackie B-3 virus myocarditis in golden hamsters. Light and electron microscopy findings in a long-term follow-up study. Fpn Circ f 1981;45:713-29.

42 Eschenhagen T, Diederich $\mathrm{M}$, Kluge $\mathrm{SH}$, Magnussen $\mathrm{O}$, Mene U, Muller F, et al. Bovine hereditory cardiomyopathy: an animal model of human dilated cardiomyopathy. $7 \mathrm{Mol}$ Cell Cardiol 1995;27:357-70.

43 Hajiar RJ, Liao R, Young JE, Fuleihan F, Glass MG, Gwathmey JK. Pathophysiological and biochemical characterisa- 
tion of an avian model of dilated cardiomyopathy: comparison to findings in human dilated cardiomyopathy Cardiovasc Res 1993:27:2212-21.

44 Gruver EJ, Glass MG, Marsh JD, Gwathmey JK. An animal model of dilated cardiomyopathy: characterisation of dihydropyridine receptors and contractile performance. $\mathrm{Am} \mathcal{F}$ Physiol 1993;265:H1704-11.

45 Liao R, Nascimben L, Friedrich J, Gwathmey JK, Ingwall JS. Cardiovascular energy reserve in an animal model of dilated cardiomyopathy. Relationship to contractile performance. Circ Res 1996;78:893-902.

46 Genao A, Seth K, Schmidt U, Carles M, Gwathmey JK. Dilated cardiomyopathy in turkeys: an anima model for the study of human heart failure. Lab Anim Sci 1996;46:399404 .

47 Chow LH, Beisel KW, McManus BM. Enteroviral infections of mice with severe combined immunodeficiency. Evidence for direct viral pathogenesis of myocardial injury. Lab Invest 1992;66:24-31.

48 Khatib R, Chason JL, Silberberg BK, Lerner AM. Age dependent pathogenicity of group B Coxsackieviruses in dependent pathogenicity of group B Coxsackieviruses in Swiss-Webster mice: infectivity for
pancreas. F Infect Dis 1980;141:394-403.
49 Woodruff JF, Woodruff JJ. Involvement of T lymphocytes in the pathogenesis of coxsackievirus B3 heart disease. 7 Immunol 1974;113:1726-34.

50 Henke A, Huber S, Stelzner A, Whitton L. The role of $\mathrm{CD}^{+} \mathrm{T}$ lymphocytes in coxsackievirus $\mathrm{B} 3$-induced myocarditis. F Virol 1995;69:6720-8.

51 Schwimmbeck PL, Badorff C, Rohn G, Schulze K, Schultheiss HP. The role of sensitised T-cells in myocarditis and dilated cardiomyopathy. Int f Cardiol 1996;54:11725.

52 Lauer B, Padberg K, Schultheiss HP, Strauer BE. Autoantibodies against cardiac myosin in patients with myocarditis
and dilated cardiomyopathy. $Z$ Kardiologie 1995;84:30110 .

53 Caforio ALP. Role of autoimmunity in dilated cardiomyopathy. Br Heart f 1994;72(suppl):S30-4.

54 Tracy S, Chapman NM, Romero J, Ramsingh AI. Genetics of coxsackievirus B cardiovirulence and inflammatory heart muscle disease. Trends Microbiol 1996;4:175-9.

55 Huber SA, Lodge PA. Coxsackievirus B3 myocarditis. Identification of different pathogenic mechanisms in DBA $/ 2$ tification of different pathogenic mechanisms
and Balb/c mice. Am f Pathol 1986;122:284-91. 